\title{
Impacts of tuna industries on coastal communities in Pacific Island countries
}

\begin{abstract}
Tuna fishing and processing industries have brought both a range of economic development and cultural contact opportunities to coastal communities in Pacific Island countries, and a variety of social and environmental challenges. This article outlines the main trends in the tuna industries of the region, examines the aspirations of coastal communities towards these industries, and traces actual experiences of their operations.
\end{abstract}

\section{Keywords}

Tuna industries, Pacific Island countries, social impacts, environmental impacts

\section{Introduction}

In the 1970s, many newly independent Pacific Island countries (PICs) envisaged national economic development driven by the tuna resources of their newly-declared 200 nautical mile exclusive economic zones (EEZs). It was the era of the New International Economic Order, when former colonies wanted to replicate the success of the Organization of Petroleum Exporting Countries (OPEC), who had reversed the colonial order of wealth extraction by extending sovereign rights over natural resources and garnering resource rents from wealthy resource-importing countries [1]. However, expectations of economic benefits from tuna altered in over the following decades, as exploration revealed the commercially available patterns of tuna resources, as each of the PIC economies developed differently, and as global tuna industries changed.

PIC coastal communities have had particular experiences of these industries. Based on qualitative research including ethnographic fieldwork conducted in 1999 and 2005, this paper focuses on interactions between coastal communities and industrial tuna industries, looking at the hopes coastal people have had, compared with the actual changes these industries have brought - including resource rents, employment, spinoff businesses, and social and environmental impacts. The issues posed by tuna industries for coastal communities are of the same as are posed by modernization and development in general - providing opportunities that people value as well as challenging social and environmental issues to resolve.

\subsection{Background: Tuna Industries in PICs}

The types of fisheries and processing facilities operating near coastal communities determine the kinds of experiences those communities have of tuna industries. Tuna resources are not evenly distributed, but vary across ecological zones. Large-scale pelagic fisheries (mainly purse-seining for skipjack) for cannery markets are most concentrated in equatorial waters. Lower volume longlining for fresh tuna markets 
(targeting bigeye and yellowfin) and cannery markets (targeting albacore) are active across a wider geographical range that includes cooler waters north and south of the equator. ${ }^{1}$ Tuna are not catchable either year round or every year in all EEZs. There are annual seasons in some areas, and several-year-cycles related to the El Niño Southern Oscillation effect also affecting fishing locations [2]. For these reasons certain kinds of industrial tuna enterprises cluster in particular zones, with transhipping hubs for large-scale purse seine vessels, tuna canneries and loining plants in or close to the equatorial zone. Countries further from the equator tend to host only longline fishing and small-scale fresh tuna processing. The overfishing of certain stocks has also affected patterns of industrial tuna fishing across the region, with small- to medium-scale locally-based longline fisheries emerging and booming in such countries as Samoa and Papua New Guinea in the 1990s, only to collapse in the early 2000s.

Apart from the distribution of the resources, other factors that affect tuna industry investments onshore include infrastructure, market access, human resources, potable water, power and government policies towards investment $[3,4]$. Factors endogenous to PICs, however, are only a few of the economic factors affecting patterns of industrial tuna enterprise, since international trade regimes are also crucial. The key point is that the biggest markets for canned tuna (the USA, EU and Japan) protect their domestic fish processing industries with tariffs. Some PICs, through being former or current British, French or US colonial territories, have preferential access to these markets, which makes their production costs competitive with cheaper production locations in Thailand and other Southeast Asian countries. Tariff structures and trade preferences are changing in response to developments in the World Trade Organization, and to the proliferation of bilateral and regional trade agreements over the last decade. These changes alter the production costs of PICs relative to other tuna processing countries, and may threaten the long-term viability of tuna processing in PICs [5].

Beliefs about the extent and nature of economic returns possible from PIC tuna resources have changed over time in response to successes and failures in tuna industries. In the 1970s and 1980s many PIC governments tried owning fishing and/or processing ventures, but most failed [4]. Therefore by the 1990s most PICs had relinquished the role of enterprise ownership. Some concluded that PICs themselves lacked competitive advantage in fishing or processing, and should focus just on maximizing resource rents through fisheries access and license fees for distant water (foreign) fleets [6]. For some PICs, like Kiribati, with severe geographic constraints in terms of available land, potable water and distance from trade routes, maximizing resource rents seems more feasible than domestic development. Other PICs with greater potential for industrial development, however, place hope in the approach taken by PNG since the mid-1990s. The PNG government has tied fisheries access to investment in onshore processing. This resulted in three large onshore factories employing thousands of people. Other development strategies tried by PIC

\footnotetext{
${ }^{1}$ For a description of purse seine and longline fishing for tuna see the Food and Agriculture Organization of the United Nations (FAO) Fisheries and Aquaculture Department's pages on fishing techniques at $<$ http://www.fao.org/fishery/fishtech/40> and

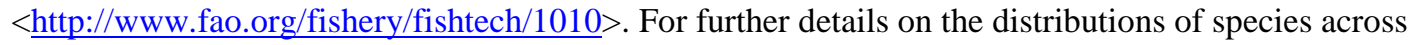
the region see the Secretariat of the Pacific Community (SPC) Oceanic Fisheries Program Regional Stock Assessment reports at $<$ http://www.spc.int/oceanfish/Html/SAM/StockAss.htm>.
} 
governments include encouraging the development of locally based longline fisheries and fresh fish processing industries (packing and sometimes filleting fish) [7].

\section{Potential Benefits for Coastal Communities}

\section{1 'We see them taking our fish and we get nothing in return'}

In a study conducted in 2005 on the aspirations of Pacific Islanders for their tuna resources, interviewees frequently cited disappointment that coastal villagers had received minimal or no benefits from tuna industries [4]. ${ }^{2}$ Sometimes this disappointment was framed in terms of villagers having customary ownership of the tuna, and thus deserving recompense. Customary rights in formal law generally do not extend over the fishing grounds targeted by industrial tuna fishers, because customary fisheries generally operated closer to shore. However, studies of customary fishing show that these systems are fluid, and beliefs about who has rights over what change over time [8,9], especially when a resource becomes valuable [10]. Whereas villagers may have no formal legal rights as customary owners of industrial tuna fishing grounds, many Pacific Islanders believe that coastal villagers have some kind of claim over those resources, and feel strongly that they should receive some benefits from their exploitation. This is related to resource nationalism in which it is believed citizens should benefit from exploitation of resources within the EEZ, but it is also felt that coastal villagers in particular should benefit from the exploitation of tuna resources. This was evident in the many projects over the years that have aimed to bring benefits from tuna industries to coastal communities, some of which are mentioned here.

In no PICs are villagers paid directly by companies for the right to catch tuna. Tuna fishing access fees (for foreign vessels) and license fees (for domestic and foreign vessels) are generally paid directly to central governments. ${ }^{3}$ This revenue could benefit coastal villagers, were it put into improved services for health, education, transport and telecommunications. Unfortunately, in PICs like PNG and Solomon Islands, government services in rural areas have decreased since Independence, for a range of reasons related to small government revenues, governance problems and competing priorities. Another way tuna fishing access fees to national government could benefit coastal villagers is use of a portion to fund coastal development projects. National tuna management plans developed in PICs since the late 1990s mostly have included a levy on tuna fishing licenses to go into a fund for rural coastal development projects. Of six PICs surveyed in 2005 (Cook Islands, Fiji, Kiribati, Marshall Islands, PNG, and Solomon Islands [4]), however, Marshall Islands was the

\footnotetext{
${ }^{2}$ Some of the interviewees who said this include: John Aini, fisheries consultant and trainer with the non-governmental organization Ailan Awareness (interview 26 May 2005, Kavieng, PNG); William Atu, Deputy Program Manager The Nature Conservancy (interview 12 July 2005, Honiara, Solomon Islands); Peter Ramohia, Research Officer, Solomon Islands Government Fisheries Department (interview 15 July 2005, Honiara, Solomon Islands).

${ }^{3}$ Solomon Taiyo Ltd (since 2001 Soltai Fishing and Processing Ltd) in Solomon Islands has paid fees to villagers via the central fisheries bureaucracy, but this was for access to reef and lagoon areas (under customary tenure) to fish for bait for the pole-and-line fishery, not for tuna fishing rights. Access for the US fleet has been organized by multilateral treaty with Pacific Islands Forum Fisheries Agency (FFA) members rather than individual PIC governments since the 1980s, and fees for this go first into a fund managed by the FFA before going out to member governments.
} 
only government to have implemented this plan. Because of PIC government choices to do other things with tuna fees, therefore, resource rents from the exploitation of tuna fisheries have rarely filtered through in cash or in kind to coastal villagers, which many Pacific Islanders feel is unjust.

Resource rents, however, are only one of various possible benefits coastal communities could receive from industrial tuna fisheries. Other kinds of hoped for benefits are opportunities to engage with the cash economy, through employment in or business with tuna companies.

\subsection{Employment}

Probably the greatest benefits coastal communities have received from industrial tuna industries have been in form of employment, particularly through onshore processing in canneries and loining plants. ${ }^{4}$ This employment has not been only for coastal villagers. Tuna canning and loining factories in PICs have been medium-scale and required workforces of hundreds or thousands, so could not be built in very remote areas. Nevertheless, most have been established outside the main urban centres, and all are on the coast, so members of nearby coastal communities often make up a large proportion of the workforce.

In Fiji since the early 1970s a cannery at Levuka, on Ovalau has employed villagers from all over the island, up to 70 percent of the available workforce. ${ }^{5}$ The Solomon Islands cannery was at Tulagi from 1973 until 1990, then moved to Noro, in Western Province. When the cannery moved to Noro management instituted a strategy of employing people who lived in coastal villages around the area and commuted to Noro, rather than having employees living only in the township of Noro itself. Tuna processing factories have been developed in PNG since the late-1990s in the regional centres of Madang, Wewak and Lae, and so have provided substantial employment opportunities for coastal communities in these areas. There are also tuna factories in Majuro, Marshall Islands and Pago Pago, American Samoa.

\section{Put Table 1 NEAR HERE}

Employment in a tuna cannery is factory work, with most jobs being considered unskilled manual labour and paid at or close to the minimum wage. Much of the work is repetitious and physically demanding. Since the main end markets of the USA, EU and Japan have very high quality criteria, and many EU and US buyers also have social responsibility criteria, pay and working conditions in tuna factories in PICs are at least as good as the national standards in those PICs [4]. But the national standards for pay are often very low. The take-home pay for the lowest ranked cannery workers in PNG and Solomon Islands is less than USD2 per day. This is partly what makes the

\footnotetext{
${ }^{4}$ Loining plants are similar to canneries, the main difference being that they do not put the fish into cans. This is an artefact of the international trading system wherein wealthy countries with domestic canning industries (several EU countries, Japan and the USA) protect those industries with tariffs, but even so their production is not competitive owing to their high labour costs, so they end up only conducting the mechanized part of the process - canning - domestically. Preparing the fish for canning is called loining and this can only be done by hand. Loining is done in countries with cheaper labour costs, with the loins sealed in plastic and frozen then exported to the canning countries. Even factories with canning capacity, such as those in Solomon Islands and Fiji, have produced more loins than cans in recent years.

${ }^{5}$ This is according to managers of the Bumble Bee cannery in Levuka interviewed in 2005.
} 
operations of those canneries viable, since global industry standards are set by the world centre of tuna processing, Thailand, where the labour costs are low. In fact, Thailand is a much cheaper and easier production location than PICs in terms of freight, cold storage, utilities, and skilled labour, so the low wages paid to Pacific Islanders are part of what makes tuna processing commercially viable in PICs. Furthermore, although wage rates are low in these PICs, there are a range of costs that make the overall cost of labour relatively high. For example, in PNG and Solomon Islands there are no effective public or private sector local transport systems so it is conventional for workplaces to provide commuter transport free of cost to employees, which according to managers in RD Tuna in Madang cost the company PGK50,000 (around USD16,000 at 2005 exchange rates) per week. In Solomon Islands employers also subsidize employee housing. These costs have been offset by a 24 per cent tariff advantage over Southeast Asian processed tuna in EU markets, but this advantage has diminished over time and is likely to diminish further [5].

Tuna industries have also provided employment opportunities on fishing vessels, open to people from coastal communities as well as others. Like urban centre-based canneries this kind of employment is not in coastal communities, so the effects are the indirect ones of people going away to work, bringing some of the cash they earn back into communities, and returning to communities with the changed worldviews that come from their experiences away at work. The pole-and-line fishery in Solomon Islands has provided the most cash work for Pacific Islanders of any of the industrial tuna fisheries. ${ }^{6}$ The Solomon Taiyo vessels were fairly low technology and highly labour intensive, and so employed large numbers of men per ton of fish caught. Furthermore, local personnel trained up to executive crew positions. Solomon Islanders made up the more than half of crews since the mid-1980s [11] and since the early 1990s made up more than 90 percent of crews. By 1999 the Solomon Taiyo Ltd fleet employed around 900 Solomon Islanders, with several vessels totally crewed by local people (including the positions of Fishing Master, Captain and Chief Engineer). This pole-and-line fleet has deteriorated, however, since the company reopened in 2001as a wholly government-owned operation. Initially the fleet was cut to less than half of its 2000 size, and subsequently lost vessels progressively, until in 2008 only one was still fishing. In the 1970s and 1980s, Fiji also had a locally-crewed pole-andline fleet. However, this collapsed in the 1990s, when pole-and-line fleets globally suffered from the competition of cheaper purse seine-caught fish.

Other fleets in PICs have provided much less employment. The purse seine vessels based in PNG connected to the onshore processing facilities typically employ a maximum of 5 local persons per crew of 35. Longline vessels based in PNG employed a higher ratio, with over 300 local persons employed at the peak of that industry in 2002 [12] (see also Table 1). Longline vessels based in several PICs, including Fiji and Cook Islands, have employed Pacific Islanders. However this is generally only on the smaller vessels that make shorter trips with frequent returns to port. Very few of the large industrial tuna fishing longline or purse seine vessels that stay out at sea for months at a time, refuelling at sea, employ any Pacific Islanders. Reasons given for this by company managers are usually about Pacific Islanders not responding well to the stressful living and working conditions of long trips and/or the

\footnotetext{
${ }^{6}$ For a description of pole-and-line fishing see the FAO Fisheries and Aquaculture Department's pages on fishing techniques at $<$ http://www.fao.org/fishery/geartype/314/en $>$. Greenpeace has published a perspective on the socially and environmentally beneficial features of this style of fishing [30].
} 
greater productivity they can get with crew from other countries like China, the Philippines, Indonesia and Vietnam, where people rely more on their cash incomes than do landowning Pacific Islanders. ${ }^{7}$ Another factor is the lack of recruitment and training systems to facilitate this kind of employment for Pacific Islanders. Many fishing companies do not own their vessels, but charter them from owners who have established crew recruitment systems in other countries. In PICs with established training and recruitment systems Pacific Islanders have become crew members on such vessels.

In 1989 Kiribati started a program of supplying crew for Japanese distant water tuna fishing vessels. A Japanese industry-funded training school and recruitment office were established in Tarawa. In 2005 there were around 325 I-Kiribati employed on Japanese vessels, and a smaller number (between 100-200) employed on Korean and Taiwanese vessels, recruited through government-owned companies that act as agents for distant water tuna vessels transhipping in Tarawa. National Fisheries Development (NFD) in Solomon Islands also hires local people on its fishing vessels, because, having the appropriate local connections, finds it is cheaper and easier to retain local crew than expatriates. NFD has Solomon Islanders working at all levels on their purse seine vessels, with expatriates only in some executive crew and management positions. In 2008 NFD was employing 120 people, most of these on vessels [13].

As for cannery work, international standards of pay for tuna fishing crews mean pay levels for general crew are very low (executive crew can earn much more). So general crew work is only likely to be taken up in PICs where the opportunities for cash work are very limited and the standards of pay low enough to make fishing costs competitive (such as Solomon Islands, PNG, Fiji and Kiribati). The hard work, low pay and hard lifestyle of industrial tuna fishing mean it is difficult to find people willing to do this work in places like Cook Islands and Marshall Islands, where people have access to better paid and easier employment options, in part due to having working rights in wealthy countries (New Zealand and the USA respectively).

\subsection{Spin-offs}

As well as employment, other benefits coastal communities have hoped for from industrial tuna industries include business opportunities, ranging from catching fish to sell to canneries, to running transport for workers. Tuna fisheries based in PIC coastal communities have rarely supplied export markets or the large tuna factories. There are a range of reasons for this, two of the most important being: 1) it is difficult for smallscale fishing to match the fuel and labour efficiencies of large scale industrial fishing - so prices are not high enough to make small-scale fishing profitable, and 2) it is difficult for village-based fisheries to meet the stringent quality standards required by the important export markets (such as keeping the fish sufficiently chilled from the time of capture to delivering it to the cold store), both in terms of meeting the standards and in terms of reporting operations in a way that is acceptable to buyers. These difficulties are related to the perishability of tuna as a commodity. Cashearning fisheries successes (not always sustainable ones) in coastal communities have tended to be from less perishable products such as dried beche-de-mer, turtle shell, a variety of shells and pearls, not fresh fish products.

\footnotetext{
${ }^{7}$ Companies whose managers expressed this opinion about the suitability of Pacific Islanders as employees on fishing vessels include RD Tuna (purse seining) and Fiji Fish (longlining).
} 
An exception to this general rule is the Samoan alia fishery, which in the late 1990s and early 2000s was generating good money for coastal fishers through tuna exports. Alias are small (9-10m in length) vessels owned and run in coastal communities. They caught albacore and other tuna species with the longline method. Many study tours were sent by PIC governments to Samoa to explore the alia model to help them develop rural coastal fisheries in a similar way. There were however several flaws in the alia model, and it has not been replicated elsewhere. One problem was that stringent food safety methods were not employed, so it was possible a food safety problem would arise and buyers stop sourcing from alias. Another problem was that the alias did not have the safety equipment needed for fishing far from shore, and dozens of fishers were lost in the space of a few years [14]. Finally the sharp increase in fishing effort in coastal waters that occurred with the success of the alia fishery caused a decline in the target fish stocks. By the mid 2000s the Samoan fishery had mostly been taken over by larger longliners that could operate further offshore where fish stocks remained in better shape, but these vessels were too expensive and high tech to be owned and operated by coastal villagers.

While the alia model has not been replicated elsewhere, there have been attempts to develop similar kinds of small-scale export-oriented commercial tuna fisheries owned and run from coastal villages. There have been several projects in PNG based on the model of 'pump boats' that saw coastal village-based small-scale fishers enter fresh tuna export markets in the southern Philippines. Constructed of wood and using lowcost diesel motors these vessels would be manageable by coastal communities in the Pacific Islands. Thus far, however, pump boats taken on by locals in PNG have mostly not been profitable [15]. Efforts to encourage Pacific Islanders to enter other kinds of small- to medium-scale longlining through providing credit in Marshall Islands and Fiji also mostly lead to defaults on loans [4].

Some village-based coastal fisheries have developed indirectly from tuna industries, however, through tuna workforces boosting local markets through increased demand for bought food. Local urban markets pay higher rates per kilo of fish than canneries and have less stringent quality standards. Streetside sales of fresh fish from cool boxes and market sales of fresh and cooked fish flourish in the areas around tuna processing factories. In addition, at least one large tuna processor has bought fish from coastal communities to help feed their workforce (as opposed to buying for export). RD Tuna in PNG bought catches from small-scale coastal fishers to use in their staff canteen as part of an EU-funded Rural Coastal Fisheries Development Programme in the mid 2000s. The project was based on the idea that village-based fishers should be able to 'piggyback' on the infrastructure and other opportunities that exist where an industrial tuna fishery and/or processing plant exists. RD Tuna was a 'private sector partner' in the project, providing access (on a commercial footing) for coastal fishers to its ice making facilities, fuel, expertise in business and financial systems, as well as a market for the catch.

Supplying baitfish is another fishing-related business in which it was hoped coastal communities would engage as part of tuna industries. Both the pole-and-line and longline methods require bait to catch tuna, either live or frozen. Solomon Islands and Kiribati both hosted projects in the 1970s and 1980s to develop village-based methods for catching and storing or breeding baitfish. Villagers never developed such 
baitfisheries, however, for a range of reasons including the mix of incentives and complications related to customary reef ownership in Solomon Islands [16] and the attractiveness of brooder fish as a human food source in Kiribati [4].

In addition to fisheries businesses, tuna industries have also generated a range of other kinds of spin-off business opportunities. In the 1990s Solomon Taiyo Ltd contracted out its cleaning and security to locally owned and run companies, and some of its commuter transport. The company also bought large amounts of fresh vegetables from farmers in surrounding areas [16]. Furthermore, since Solomon Taiyo moved its main base to Noro in 1990, a town has grown up around the fishing base, providing a range of services as well as opportunities for neighbouring coastal communities. There are banks, a telecommunications office, stores (some owned and run by locals), and a thriving fresh food market. RD Tuna in Madang contracts local companies for services such as stevedoring.

The opportunities for spin-off businesses from tuna industries have not been taken up by coastal communities as much as development planners might hope. While many coastal villagers take up cash employment for a time, or produce things to sell for cash, few end up developing businesses as such. This phenomena is not restricted to coastal people, but has been noted for village-based people as a whole in countries like PNG. One explanation is that while the desire for cash and engagement with the cash economy is quite strong, village-based people do not embrace capitalism as a whole. Rather, village economies remain something other than capitalist, and the cash economy is engaged in as an extension of the village economy, not as a modernization process in which the village economy is replaced by capitalism [17].

\section{Negative Impacts}

\subsection{Social impacts}

Cash employment and increased opportunities for business do not only bring benefits, however. Cash employment among village women at the Noro cannery changed the dynamics of village life in ways that were not always seen as positive. For example, Solomon Islander village-dwelling women had unpaid work at home that remained their responsibility even when they took up full time work at the Solomon Taiyo cannery. Work plus the long commute to and from Noro often meant women were absent from the village for twelve hours a day five days a week and slightly less on Saturdays. Husbands who did not work outside the village often took on childminding roles, but tended not to take on the jobs of food preparation or cleaning. Women without women relatives helping them then had to try to do this work while at home, which was exhausting, and sometimes lowered standards of nutrition for themselves and/or families [18].

People who go away for work at canneries or on fishing vessels may also have problems settling back into village life after their period of employment has ended. No doubt many people do adjust back into village life successfully, but interviewees also talked of people who no longer wanted to participate in communal village work, who developed alcohol problems while away, or whose marriages broke down under the strain of long absences. ${ }^{8}$

\footnotetext{
${ }^{8}$ Interviewees who talked of such problems include Nauan Bauro General Manager, Kiribati
} 
The increase in numbers of fishing vessels, among other kinds of international shipping services, has also contributed to social trends often seen as detrimental. These ships are usually crewed exclusively by males and there is pervasive a culture of 'hard partying' when they come ashore. Substance abuse and sex work (or various other kinds of sexual arrangements disapproved of by the wider community) are often involved. ${ }^{9}$ This is seen as increasing social problems such as unplanned pregnancies, violence and sexually transmitted infections [19]. Contact with crew is often around large ports in urban areas but it also occurs in rural coastal communities. For example, Solomon Taiyo's pole-and-line vessels moored in coastal areas in the afternoons before commencing baitfishing after dark, so interacted with coastal villagers daily. The full social reality of these situations was complex, and not only negative, but interviewee representations of contact with fishing vessels usually fore grounded the alcohol consumption, violence and disapproved-of sexual relationships that occurred between villagers and crews [16]. In PNG there are various places around the country where industrial tuna fishing vessels dock while transhipping their catch to carrier vessels [4]. Contact between crews supplying the RD Cannery and local people in the Madang area has certainly been widely seen as generating negative social impacts [20]. The coming and going of industrial vessels from Levuka in Fiji since the 1950s, as well as the cash earning opportunities of the cannery once it opened in the 1970s, resulted in various negative social impacts in Ovalau [21], including the island having a reputation for excess alcohol consumption. ${ }^{10}$

Other kinds of social change resulting from tuna industries that may be experienced as negative social impact in coastal communities relate to the ethnic mixing and migration necessary to generate sufficient workforces. This may involve influxes of people from overseas, especially from fishing fleets around wharf areas, and may also include mixing of sub national ethnic groups. Not every tuna industry has caused large scale ethnic mixing; the Fiji Pafco cannery sources the majority of its workforce from Ovalau with only a small number of high ranked positions filled from outside the area, and canneries in urban areas like Majuro or Pago Pago do not as noticeably change their social environment because urban social environments are already mixed. In PNG and the Solomon Islands, however, ethnic mixing through tuna industries stands out as a social issue.

The Soltai cannery and fleet at Noro required more workers than the surrounding area could supply so has been a magnet for internal migration from around the country, and the tuna plants in PNG have also attracted internal migrants. In both Solomon Islands and PNG sub national regional identities are very strong, as is mutual chauvinism between these groups. In conjunction with traditions of customary tenure, inadequate services and infrastructure mean there are intractable problems with housing to facilitate such migration, so internal labour migration is very much viewed as a social problem. One of the ways this has manifest in Madang in PNG is a strong sense of injustice on the part of the local groups who were dispossessed (in the colonial era) of the land that the cannery and wharf now occupy, and who believe that

Fisherman’s Services Company Limited (interview 13 October 2005, Bairiki, Tarawa, Kiribati); Teorae Kabure Principal, Fisheries Training Centre (interview 13 October 2005, Bikenibeu, Tarawa, Kiribati).

${ }^{9}$ Connections between fisheries and sex work are the subject of much speculation but little concrete evidence has been published [31].

${ }^{10}$ Inoke Navuetaki, Pafco Public Relations Officer (interview 26 September 2005, Levuka, Fiji). 
their disadvantage (in now having no land) should be compensated for by the company prioritizing them over other Papua New Guineans for opportunities in employment and spin-off businesses [20].

When Solomon Taiyo was at the peak of its production in the late 1990s and employing more than 2,500, there were frequent bouts of fighting between young men of the different ethnic groups living around Noro. This violence rarely resulted in serious injury and was considerably less disruptive than the inter-ethnic violence on Guadalcanal that rendered the Solomon Islands state inoperable from 2000-2003 and necessitated international intervention. Nevertheless, the inter-ethnic problems that have occurred in Noro and around PNG tuna factories are experienced by coastal communities as a negative social impact from industrialization, and certainly should be addressed as part of government policy toward tuna industries.

\subsection{Environmental impacts}

Tuna industries, like any other kind of industrial development, inevitably impact on surrounding ecosystems. The two main environmental concerns people have with tuna industries are stock depletion (either target fish stocks or incidentally killed animals) and pollution.

PIC coastal communities have been particularly concerned about the possible depletion of the stocks of fish they rely on for food and livelihoods. Most of the research about the sustainability of catches of tuna industries in the Pacific focuses on the effects of fishing mortality on the overall biomass of the four commercially targeted species in the region (skipjack, yellowfin, bigeye and albacore). Skipjack and albacore stocks seem to be coping with current levels of fishing, but yellowfin and bigeye stocks have shown evidence of stress for a decade or more. ${ }^{11}$ Research rarely focuses on the effects of industrial tuna fisheries on food/livelihood fisheries so there is limited evidence about whether industrial tuna fisheries are having a negative impact, and there is a lack of comparable baseline data about coastal marine resources in PICs. ${ }^{12}$ In many cases the tunas exploited by industrial offshore fisheries are not the same stocks coastal villagers target. Villagers in countries with extensive reef and lagoon systems tend to catch varieties of reef fish more than the pelagic tunas, although in atoll countries, such as Kiribati, tunas can make up the majority of artisanal food and livelihood catches. Industrial tuna fisheries could also affect coastal catches in non-atoll countries where villagers have access to Fish Aggregation Devices that attract pelagic fish, or where pelagic migration routes come close enough to shore to enable easy catching by small vessels.

The baitfisheries attached to pole-and-line tuna fisheries have taken fish from reef areas used by coastal communities in Solomon Islands and Fiji in the past, but currently there are no significant pole-and-line fisheries operating in PICs. The Solomon Taiyo baitfishery was widely believed to be depleting stocks of fish in lagoons from the earliest days of the company in the 1970s [16]. Government statistics on baitfish catches, however, indicated no decline in catch per unit of effort for baitfisheries, and since the early 1980s the catch data collection system had been designed to contain no incentives to underreport catches (baitfishing royalties were

\footnotetext{
${ }^{11}$ For scientific reports on these stocks see $<$ http://www.wcpfc.int/>.

${ }^{12}$ Simon Foale (personal communication [email] 1 August 2008).
} 
based on fishing nights, which could be independently verified by villagers, rather than on catches) [22]. Research into whether the baitfishery was trophically related to food/livelihood species indicated it was not $[23,24]$, however, this work did not consider the full range of food/livelihood fishing conducted by coastal communities. Other researchers found that some food/livelihood fisheries (particularly night-time droplining for barracuda species) were trophically related to the baitfisheries in Solomon Islands and Fiji [25]. It would be interesting to see if food/livelihood catches in baitfish grounds have recovered at all since 2000, after which the baitfishing effort dropped by more than half, and thereafter shrank annually to virtually nothing by 2008.

Notwithstanding the lack of evidence about impacts of industrial tuna fishing on stocks of fish commonly caught for food and cash by coastal communities, many Pacific Islander fishers and expatriate game fishing enthusiasts believe commercial tuna fishing is depleting coastal resources because they have experienced declining catches in the decades since industrial tuna fishing started. Due to a lack of available data on coastal marine resources, it is hard to say precisely what is happening, but there are several possible explanations in addition to industrial tuna fisheries. One explanation is that in the decades since industrial fisheries started operating around PICs coastal community population sizes have grown greatly. Larger coastal populations mean more fishing pressure. Increased populations can also mean more pollution, since there are generally insufficient sewage and rubbish systems to prevent pollution from coastal villages. In some places ill-managed logging has also damaged fragile reef and lagoon ecosystems. In some areas Pacific Islanders use dynamite or other kinds of destructive fishing practices. Traditional systems of coastal resource management have in some areas broken down, and where they have survived are not sufficiently conservationist to meet the pressures of cash-oriented (as opposed to food-oriented) fishing [26]. PIC Governments have mostly not responded effectively to the need for state-run resource management systems to supplement communitybased resource coastal resource management, although positive moves in this direction have been made in countries such as Samoa and Fiji. As yet coastal population pressures in PICs are much less than most other parts of the world, so coastal fisheries are still relatively healthy [27], but it is possible coastal community activities among other factors have contributed to the decrease in catch per unit of effort coastal communities report, and often attributed solely to industrial tuna fishing.

Tuna industries can also generate pollution. Large canning and loining factories generate large amounts of waste. Solid fish waste material canned be buried in landfill, but these days most canneries, including in PICs, tend to dry and crush the bones, skin and other solid fish waste into fishmeal, that can be sold as animal feed and therefore generate income. Waste water comes from boiling fish, from the large amounts of water used to clean food preparation areas, floors and so on, as well as from the toilets and kitchens attached to factories. Canneries and loining plants usually have a waste water treatment plant on site, but in the case of both Solomon Taiyo and RD Tuna this did not prevent some serious pollution problems arising. Solomon Taiyo and its wholly government-owned successor Soltai Fishing and Processing have had ongoing problems with waste water. The Solomon Taiyo waste water treatment plant was assessed in the 1990s by independent experts as being sufficient for the factory, however, it was frequently out of action due to equipment breakdowns or running out of the chemicals used in the plant. When the treatment 
plant was out of action the cannery's waste water went untreated straight into the sea next to the cannery. Furthermore, the plumbing of some parts of the plant (such as the fishmeal plant in the 1990s) were not connected to the waste water treatment plant at all, so water from those areas went straight into the sea. A water quality study of the sea around Noro found significant levels of pollution, even though tidal flows washed a lot of the pollution away each day [28]. Financial pressures since the company became wholly government owned in 2001 prevented the upkeep of the waste water treatment plant was so from then all waste water has gone untreated into the sea. Other pollutants going directly into the sea at Noro include diesel sludge from the government-owned power plant, bilge and rubbish dumped from fishing vessels at the wharf, and domestic and household waste from the inhabitants of Noro. Noro inhabitants believe the water is polluted and worry about the safety of swimming or eating fish caught in Noro waters. There were also periodic problems for coastal communities in other locations from Solomon Taiyo vessels dumping bilge waste in lagoons, which meant black sludge petroleum residues in coastal areas, including in areas used for fishing and gleaning. ${ }^{13}$

The RD Tuna cannery in PNG also caused pollution with waste water in 2003-4. Water from the cannery proper was apparently being treated effectively, but the waste water from the factory toilets and kitchen was not plumbed into the waste water system, it was going untreated into a nearby stream. Furthermore, for a period of time the toilets for cannery workers were out of order, so hundreds of workers were using a nearby field, and when it rained this sewage was washing into nearby streams. Complaints about the smell coming from these streams prompted a government inquiry, which lead to these problems being rectified by the company in 2004. A report into water quality of the Madang Lagoon found that the lagoon was somewhat polluted but that it was not clear that RD Tuna was causing all or even most of this pollution [29].

Like in Noro, there were also pollution problems in the RD Tuna wharf area, which were not all caused by the company. One problem was decomposing tuna. Fishing crews usually did not throw fish overboard, most fish was transferred to cold storage with the small amounts of fish rejected for canning purposes sold or traded with locals who then sold the fish on to the public, or cooked it and sold it in the market. But local stevedores who obtained fish often stored it underwater (in the absence of a refrigerator) and if they failed to retrieve it later the decomposing fish became a problem. In one case RD crew were found to be at fault - the freezing system on a vessel had broken down, contaminating a load of fish with Freon. Since the fish was not suitable for the cannery or the local fish buyers it should have been taken to the local dump but crew instead dumped it overboard at the wharf.

\section{Conclusion}

Tuna industries have offered coastal communities the same conundrum economic development has offered PIC villages more generally. They bring benefits, such as opportunities to engage with the modern world and to earn cash, but also problems, including overfishing, pollution and exacerbation of problems associated with social

\footnotetext{
${ }^{13}$ Complaints about bilge waste from Solomon Taiyo vessels periodically polluting lagoon areas were contained in letters to the Noro Town Council and Western Province government in files explored in 1999.
} 
change. The mix of benefits and problems experienced by coastal communities has varied according to whether the tuna industry is a large cannery, large-scale foreignowned fleet, a smaller-scale locally based longline fishery, a pole-and-line fishery with an associated baitfishery, or some combination of these. Canneries, and to a lesser extent locally-based fisheries, have generated the greatest impacts, both positive and negative.

The ambiguous nature of this kind of economic development is encapsulated in two features of Pacific Islander coastal community responses to tuna industries. One is that cash employment and business opportunities opened up through tuna industries have lead to social change, but not lead to coastal villagers turning into fully cashdependent wage labourers or capitalists. Coastal communities have engaged with tuna industries from within the framework of their non-capitalist village socio-economies. The other is a predisposition to expect negative impacts from tuna industries, manifest in a tendency to disproportionately blame tuna industries for social and environmental problems experienced in coastal communities. Some of the social and environmental problems attributed to tuna industries are caused by those industries, but quite a lot of these problems are not, and some indeed are caused by coastal communities themselves. Development planners and investors should be aware of the particular social and cultural reception of tuna industries in Pacific Islands coastal communities as one of the factors to take into consideration for any new ventures.

\section{Acknowledgements}

The research in this paper was from doctoral studies at the University of Technology Sydney (funded by an Australian Postgraduate Award and a Japanese Monbusho scholarship), and a postdoctoral fellowship at the Australian National University (funded by AusAID). The paper benefited greatly from comments by Ken Ruddle and discussions with Simon Foale.

\section{References}

[1] Schurman R. Tuna dreams: resource nationalism and the Pacific Islands' tuna industry. Development and Change 1998;29:107-136.

[2] Lehodey P, Bertignac M, Hampton J, Lewis A, Picaut J. El Niño Southern Oscillation and tuna in the western Pacific. Nature 1997;389(16 October):715718.

[3] Clarke L. Pacific 2020 Background Paper: Fisheries. Pacific 2020 Report and Conference Project, funded by the Australian Government (AusAID), conference held 10-12 May 2006 Hilton Hotel Sydney.

[4] Barclay K, Cartwright I. Capturing Wealth from Tuna: Case Studies from the Pacific. Canberra: Asia Pacific Press; 2007.

[5] Campling L, Havice E, Ram-Bidesi V, Grynberg R. Pacific Island Countries, The Global Tuna Industry and the International Trade Regime - A Guidebook. Honiara, Solomon Islands: Forum Fisheries Agency; 2007.

[6] Petersen E. Economic Policy, Institutions, and Fisheries Development in the Pacific. Marine Policy 2002;26:315-324.

[7] Gillett R. A Study of Tuna Industry Development Aspirations of FFA Member Countries. Report prepared for the Pacific Islands Forum Fisheries Agency (FFA), Honiara; 2008. 
[8] Foale S, Macintyre M. Dynamic and Flexible Aspects of Land and Marine Tenure at West Nggela: Implications for Marine Resource Management. Oceania 2000;(71): 30-44.

[9] Macintyre M, Foale S. Land and Marine Tenure, Ownership and New Forms of Entitlement on Lihir: Changing Notions of Property in the Context of a Goldmining Project. Human Organization 2007;66(1):49-59.

[10] Ruddle K. External forces and change in traditional community-based fishery management systems in the Asia-Pacific Region. Maritime Anthropological Studies 1994;6(1-2):1-37.

[11] Barclay K, Wakabayashi Y. Solomon Taiyo Ltd: tuna dreams realized? Pacific Economic Bulletin 2000;15(1):34-47.

[12] Gillett R. Domestic tuna industry development in the Pacific islands. The current situation and considerations for future development assistance, FFA Report 03/01. Honiara, Solomon Islands: Pacific Islands Forum Fisheries Agency; 2003.

[13] Barclay K. Fisheries and aquaculture. In: Gay D. (ed) Solomon Islands Diagnostic Trade Integration Study. Geneva: Integrated Framework, implemented by the United Nations Development Program Honiara office; 2008.

[14] Food and Agriculture Organization of the United Nations (FAO). Samoa Country Profile: Fisheries. FID/CP/SAM Rev.3, April 2002. Available at: $<$ http://www.fao.org/fi/oldsite/FCP/en/WSM/profile.htm> ; cited 11 May 2009.

[15] Kinch J. A Review of the Fisheries Credit Scheme to Date in Papua New Guinea. Report for the EU Development of Fisheries in Pacific ACP Countries (DEVFISH) Project, Honiara: Forum Fisheries Agency (FFA), implemented by the FFA and Secretariat of the Pacific Community; 2008.

[16] Barclay K. A Japanese Joint Venture in the Pacific: Foreign Bodies in Tinned Tuna. London: Routledge; 2008.

[17] Curry GN. Markets, Social Embeddedness and Precapitalist Socitieties: the Case of Village Tradestores in Papua New Guinea. Geoforum 1999;(30):285-298.

[18] Sasabe M. A Woman's Story: Japan's economic involvement in the Pacific. Suva: Pacific Conference of Churches; 1993.

[19] South Pacific Forum Secretariat. Gender Issues in the Tuna Industry. Background Reports to National Tuna Management and Development Plans. Pacific Examples, Vol. 1. Suva, Fiji: South Pacific Forum Secretariat, CanadaSouth Pacific Ocean Development (C-SPOD), Forum Fisheries Agency (FFA), Secretariat of the Pacific Community (SPC); 2000.

[20] Sullivan N, Warr T, Rainbubu J, Kunoko J, Akauna F, Angasa M, Wenda Y. Tinpis Maror: A Social Impact Study of Proposed RD Tuna Cannery at Vidar Wharf, Madang. Madang, Papua New Guinea: Nancy Sullivan and Associates; 2003.

[21] Emberson-Bain A. (ed.) Sustainable Development or Malignant Growth?: Perspectives of Pacific Island Women. Suva, Fiji: Marama Publications; 1994.

[22] Barclay K. Fishing. Western, Japanese and Islander Perceptions of Ecology and Modernization in the Pacific. Japan Focus online journal 2007. Available at < http://japanfocus.org/-Kate-Barclay/2508> ; cited 18 May 2009.

[23] Blaber SJM, Milton DA, Rawlinson NJF. Tuna Baitfish in Fiji and Solomon Islands, proceedings (no. 52) of a workshop, Suva, Fiji, 17-18 August 1993. 
Canberra: Australian Council for International Agricultural Research (ACIAR); 1993.

[24] Blaber SMJ, Copland JW. Tuna Baitfish in the Indo-Pacific Region, proceedings (no. 30) of a workshop, Honiara, Solomon Islands, 11-13 December 1989. Canberra: Australian Council for International Agricultural Research (ACIAR); 1990.

[25] Johannes RE, Freeman MMR, and Hamilton RJ. Ignore Fishers' Knowledge and Miss the Boat. Fish and Fisheries 2000;1:257-271.

[26] Foale S. Sharks, Sea Slugs and Skirmishes: Managing Marine and Agricultural Resources on Small, Overpopulated Islands in Milne Bay, PNG. Canberra: Resource Management in Asia Pacific Program, Research School of Pacific and Asian Studies, Australian National University; 2005.

[27] Foale S. Conserving Melanesia's Coral Reef Heritage in the Face of Climate Change. Historic Environment 2008;21(1):30-36.

[28] Mani L. An Assessment of Fish Cannery Effluent Discharge on Pollution Status of the Noro Sea Front, Western Province. Honiara: Solomon Islands College of Higher Education; 1994.

[29] Benet Monico A. Madang Lagoon Water Quality Monitoring. Madang, Papua New Guinea: World Wild Fund for Nature South Pacific Program; 2003.

[30] Stone R, Toribau L, Tolvanen S. Developing Sustainable and Equitable Pole and Line Fisheries for Skipjack. Amsterdam: Greenpeace International; 2009. Available from<enquiries@greenpeace.org>.

[31] Béné C, Marten S. Women and Fish-for-Sex: Transactional Sex, HIV/AIDS and Gender in African Fisheries. World Development 2008;36(5):875-899.

[32] Gillett R, Lightfoot C. Contribution of Fisheries to the Economies of Pacific Island Countries, Pacific Studies Series. Manila: Asian Development Bank; 2002. 